\title{
Insulin-like growth factor 1 and insulin-like growth factor binding protein 2 serum levels as potential biomarkers in differential diagnosis between chronic pancreatitis and pancreatic adenocarcinoma in reference to pancreatic diabetes
}

\author{
Barbara Włodarczyk ${ }^{1}$, Anna Borkowska르. Przemysław Włodarczyk ${ }^{3}$, Ewa Małecka-Panas ${ }^{1}$, Anita Gąsiorowska ${ }^{4}$ \\ ${ }^{1}$ Department of Digestive Tract Diseases, Medical University of Lodz, Lodz, Poland \\ ${ }^{2}$ Department of Internal Medicine and Diabetology, Medical University of Lodz, Lodz, Poland \\ ${ }^{3}$ Faculty of Economics and Sociology, University of Lodz, Lodz, Poland \\ ${ }^{4}$ Clinic of Gastroenterology, Medical University of Lodz, Lodz, Poland
}

Gastroenterology Rev 2021; 16 (1): 36-42 DOI: https://doi.org/10.5114/pg.2020.95091

Key words: chronic pancreatitis, insulin-like growth factor 1, insulin-like growth factor binding protein 2, pancreatic cancer, pancreatic diabetes.

Address for correspondence: Barbara Włodarczyk MD, Department of Digestive Tract Diseases, Medical University of Lodz, 22 Kopcińskiego St, 90-153 Lodz, Poland, e-mail: barbara.wlodarczyk@gmail.com

\begin{abstract}
Introduction: Insulin-like growth factor 1 (IGF-1) has been connected with development of pancreatic ductal adenocarcinoma (PDAC).

Aim: To evaluate the serum concentration levels of IGF-1 and insulin-like growth factor binding protein 2 (IGFBP-2) in patients with chronic pancreatitis (CP) and PDAC. Their values in diabetes mellitus (DM) were also assessed.

Material and methods: The study included 83 patients with CP, 92 patients with PDAC, and 20 subjects as a control group. The concentrations of IGF-1 and IGFBP-2 were estimated with ELISA (Corgenix UK Ltd, R\&D Systems).

Results: The IGF-1 was higher in CP compared with PDAC $(81.11 \pm 57.18 \mathrm{ng} / \mathrm{ml} v \mathrm{vs} .53 .18 \pm 36.05 \mathrm{ng} / \mathrm{ml}, p<0.001)$, and both $\mathrm{CP}$ and PDAC were different from controls $(81.11 \pm 57.18 \mathrm{ng} / \mathrm{ml} \mathrm{vs.} 70.66 \pm 16.57 \mathrm{ng} / \mathrm{ml}, p<0.001$ and $53.18 \pm 36.05 \mathrm{ng} / \mathrm{ml} \mathrm{vs}$. $70.66 \pm 16.57 \mathrm{ng} / \mathrm{ml}, p<0.001)$. CP without cysts have lower IGF-1 compared to those with CP and cysts $(60.35 \pm 34.68 \mathrm{ng} / \mathrm{ml} \mathrm{vs}$. $93.55 \pm 64.78 \mathrm{ng} / \mathrm{ml}, p<0.05)$. IGF-1 in CP without DM was higher compared to IGF-1 in PDAC without DM $(91.13 \pm 65.48 \mathrm{ng} / \mathrm{ml}$ vs. $54.75 \pm 40.41 \mathrm{ng} / \mathrm{ml}, p<0.001)$. In CP and DM the IGF-1 was elevated in comparison to PDAC and DM $(62.20 \pm 32.38 \mathrm{ng} / \mathrm{ml}$ vs. $48.45 \pm 24.88 \mathrm{ng} / \mathrm{ml}, p<0.05)$. IGFBP-2 was higher in CP compared to PDAC $(512.42 \pm 299.77 \mathrm{ng} / \mathrm{ml}$ vs $301.59 \pm 190.36 \mathrm{ng} / \mathrm{ml}$, $p<0.001)$. In CP and PDAC the IGFBP-2 level was elevated compared to the control group $(512.42 \pm 299.77 \mathrm{ng} / \mathrm{ml}$ vs. 51.92 $\pm 29.40 \mathrm{ng} / \mathrm{ml}, p<0.001$ and $301.59 \pm 190.36 \mathrm{ng} / \mathrm{ml}$ vs. $51.92 \pm 29.40 \mathrm{ng} / \mathrm{ml}, p<0.001)$. IGFBP-2 in CP without DM was higher compared to PDAC without DM (559.39 \pm 281.43 vs. $296.53 \pm 196.93, p<0.001)$.

Conclusions: IGF-1 and IGFBP-2 may be biomarkers of CP and PDAC. IGF-1 may be an indicator that signals whether pancreatic diabetes is from CP or PDAC.
\end{abstract}

\section{Introduction}

The causes of diabetes in both chronic pancreatitis (CP) and pancreatic ductal adenocarcinoma (PDAC) have not yet been fully explained. Carbohydrate metabolism disorders may result from absolute insulin deficiency and peripheral insulin resistance [1]. Most of the patients with pancreatic diabetes come from the group diagnosed with CP $(76 \%)$. The second most frequent reason for this type of diabetes is PDAC (9\%) $[1,2]$. Due to the lack of sensitive and specific markers to distinguish CP from PDAC in clinically difficult cases, it is advisable to look for new markers that differentiate these two diseases. The detection of a marker indicating PDAC at an early stage of its development 
based on the coexistence of pancreatic diabetes would be a breakthrough.

In patients with $C P$, the dynamics of the endocrine disorders depend on the aetiology and duration of the disease. There is a convergence between exo- and endocrine disorders [2, 3]. In alcoholic CP, endocrine failure usually occurs in the advanced stage of the disease, after about 8-10 years [3]. The development of endocrine disorders in the course of CP results from a decrease in insulin secretion, caused by progressive fibrosis of the organ, damage and loss of $\alpha$ - and $\beta$-cells of pancreatic islets [4]. In patients with CP, progressive insulin resistance also occurs [5]. In the pathogenesis of diabetes development there is also a malfunction of incretin hormones, disturbances of microcirculation and impaired hepatic gluconeogenesis inhibition by insulin [6].

Data confirming the relationship between longstanding type 2 diabetes and the increased risk of PDAC come from numerous epidemiological studies [7]. The phenomenon of insulin resistance and hyperinsulinaemia probably results in increased pancreatic islet proliferation, which may predispose to the development of cancer [8]. On the other hand, it has been proven that newly detected diabetes after the age of 50 years significantly indicates recognition of PDAC [7]. One of the likely signals to start carcinogenesis is a change in the differentiation and function of pancreatic islet cells [8]. The participation of these cells in the neoplastic process is also confirmed by the presence of carbohydrate metabolism disorders in the case of small tumours located on the periphery of the organ. Moreover, in the development of diabetes in the course of PDAC, the participation of diabetogenic proteins synthesised by the tumour and progressive insulin resistance is mentioned $[8,9]$.

Lots of studies show close links between the IGF axis and glucose metabolism, including pancreatic diseases [10]. The insulin-like growth factor (IGF) axis consist of two growth factors, IGF-1 and IGF-2, in addition to several IGF binding proteins (IGFBP-1 to IGFBP-6), which work together to regulate the amount of free IGF-1 and IGF-2 in serum [11]. IGFs have structural homology to insulin, playing an important role in proliferation and differentiation of normal and malignant cells $[11,12]$. The IGFs bind to three cell-surface transmembrane receptors: IGF-1R (type 1 IGF receptor), IGF-2R (type 2 IGF receptor), and IR (insulin receptor) [12].

IGF-1 has a wide variety of effects, but, essentially, these can be divided into acute metabolic effects and long-term growth-promoting effects [11]. The acute actions of IGF-1 overlap with those of insulin on carbohydrate and protein metabolism to promote energy storage. They include stimulation of amino acid uptake into skeletal muscle and stimulation of peripheral glucose uptake. Its long-term effects are on cell proliferation, differentiation, and anti-apoptosis [13]. IGF-1 plays a role in the regulation of $\beta$-cell mass and the regulation of insulin secretion and sensitivity [14]. Insulin could stimulate hepatic IGF-1 synthesis and suppress hepatic IGFBP-1 synthesis in the liver, which could lead to an increase in the serum concentration of IGF-1 [15]. IGF-1 and the IGF-1 receptors are highly expressed on the surface of pancreatic cancer cell lines, which initiate intracellular signalling transduction associated with proliferation, invasion, and expression of mediators of angiogenesis [16]. Numerous studies have shown a relationship between IGF-1 levels, body fat, and peripheral insulin resistance [17]. Adipose tissue is one of the sources of IGF-1 production, and the peripheral insulin resistance occurring in the course of obesity affects the concentration of this protein [18].

The data highlights the importance of local IGF-1 production in regulating cell differentiation/proliferation and supports the concept that tissue-derived IGF binding proteins may represent a potential substrate capable of modifying autocrine/paracrine IGF-1 effects [19]. Quantification of the corresponding proteins in plasma might be useful for PDAC diagnosis. IGFBP-2 has the ability to discriminate PDAC patients at an early stage from healthy controls, and it appeared to be increased in diseases posing a risk of pancreatic malignancy [20]. There is abundant evidence that IGFBP-2 plays a role in the promotion of various cancers [21]. The interaction of the Arg-Gly-Asp motif in IGFBP-2 with integrins typically results in stimulatory effects towards cancer cells [22]. Moreover, nuclear transport of IGFBP-2 is reported to be associated with a tumourigenic effect by promoting angiogenesis through activation of VEGF transcription [23].

\section{Aim}

The aim of this study was to evaluate the serum concentration levels of IGF-1 and IGFBP-2 in patients with CP and newly diagnosed PDAC. Their values in patients with $C P, P D A C$, and concomitant diabetes mellitus (DM) were also assessed.

\section{Material and methods}

The study included 83 patients with CP, 92 patients with PDAC diagnosed within the last 6 months, and 20 healthy controls. The study included 83 patients with CP -62 men and 21 women. The mean age of the men was $29-79$ years ( $46.68 \pm 12.60$ years), and the women $26-78$ years ( $51.23 \pm 15.18$ years). Ninety-two patients had PDAC diagnosed within the last 6 months -49 men and 43 women, men aged $36-94$ years $(66.56 \pm 10.90$ 
Table I. IGF-1 and IGFBP-2 levels in the CP, PDAC, and control groups

\begin{tabular}{|c|c|c|c|c|}
\hline Parameter studied & $83 \mathrm{CP}$ & 92 PDAC & 20 Control group & $P$-value \\
\hline IGF-1 [ng/ml] & $81.11 \pm 57.18$ & $53.18 \pm 36.05$ & $70.66 \pm 16.57$ & $<0.001$ \\
\hline IGFBP-2 [ng/ml] & $512.42 \pm 299.77$ & $301.59 \pm 190.36$ & $51.92 \pm 29.40$ & $<0.001$ \\
\hline
\end{tabular}

CP-chronic pancreatitis, PDAC - pancreatic adenocarcinoma, IGF-1 - insulin-like growth factor 1, IGFBP-2 - insulin-like growth factor binding protein 2.

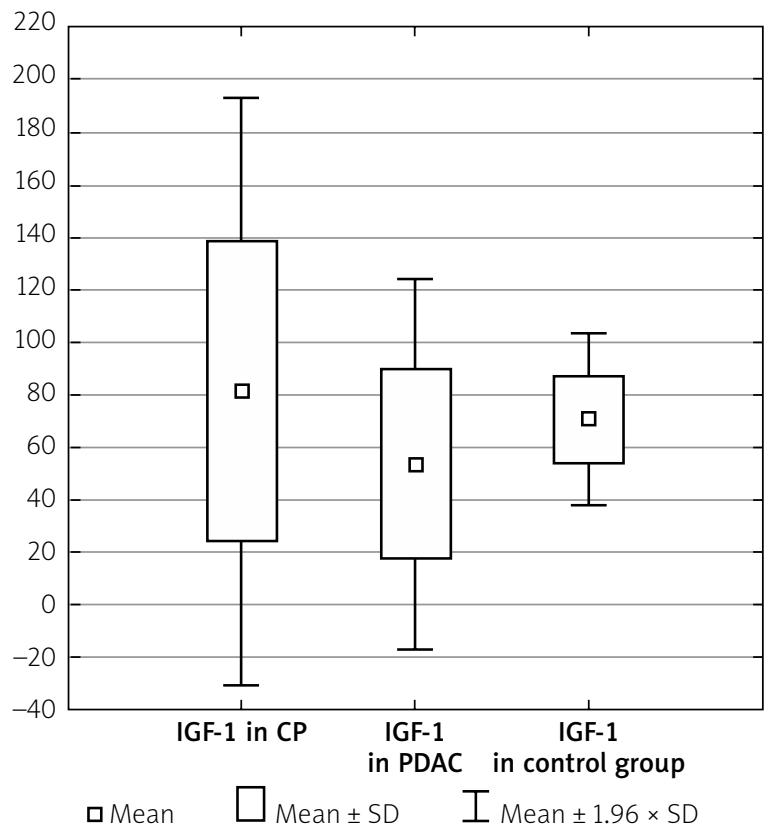

Figure 1. IGF-1 level in the CP, PDAC, and control groups

$C P$ - chronic pancreatitis, PDAC - pancreatic adenocarcinoma, IGF-1 - insulin-like growth factor 1.

years), women aged $41-86$ years (64.51 \pm 9.98 years), and 20 controls -12 men and 8 women, aged 37-63 years ( $48.4 \pm 12.56$ years).

The diagnosis of CP was based on the clinical picture and imaging (ultrasonography, computed tomography, endosonography), according to the Cambridge criteria. The diagnosis of $C P$ required visualisation of the following abnormalities in imaging tests: parenchymal/ductal calcifications, dilatation and/or irregularities in the walls of the main pancreatic duct or secondary ducts. CP on alcohol aetiology was diagnosed when consuming alcohol in the amount of $60 \mathrm{~g}$ a day during the last 2 years and after excluding other toxic, metabolic, and barrier factors. PDAC was diagnosed with at least two imaging techniques and confirmed with a histopathology of a surgical specimen or endosonography with fine needle aspirate cytology (EUS-FNA).

The blood samples were collected from each patient with CP, PDAC, and the control group after overnight fasting. The concentrations of IGF-1 and IGFBP-2 were measured in serum with ELISA (Corgenix UK Ltd, R\&D Systems).
The study was undertaken under strict ethical guidelines, and every participant signed informed consent to document their clinical data. The study was approved by the Ethics Committee of the Medical University of Lodz under the reference number RNN/108/15/ KE on 21 April 2015.

\section{Statistical analysis}

Introductory statistical analysis of the data used parametric and non-parametric tests. The Shapiro-Wilk test was used to determine whether the data were normally distributed. In such a case Student's $t$-test and the Cochrane-Cox test were used in order to assess the hypothesis of equality of means between samples. In the case of data with abnormal distribution, the $U$ Mann-Whitney test was used to determine the equality of means between samples. A $p$-value of $<0.05$ was considered statistically significant. Data presented in the text are expressed as mean \pm standard deviation (S.D).

\section{Results}

Mean body mass index (BMI) was $22.58 \pm 5.31 \mathrm{~kg} / \mathrm{m}^{2}$ in CP, $23.73 \pm 6.58 \mathrm{~kg} / \mathrm{m}^{2}$ in PDAC, and $24.93 \pm 4.14 \mathrm{~kg} / \mathrm{m}^{2}$ in the control group. DM was diagnosed in 27 patients with CP $(32.5 \%)$ similarly to the PDAC group with 30 subjects with DM (32.6\%).

The serum IGF-1 level was significantly higher in the CP group compared with the PDAC group (81.11 \pm 57.18 $\mathrm{ng} / \mathrm{ml}$ vs. $53.18 \pm 36.05 \mathrm{ng} / \mathrm{ml}, p<0.001$ ), and both CP and PDAC patients differed from controls $(81.11 \pm 57.18$ $\mathrm{ng} / \mathrm{ml}$ vs. $70.66 \pm 16.57 \mathrm{ng} / \mathrm{ml}, p<0.001$ and 53.18 $\pm 36.05 \mathrm{ng} / \mathrm{ml}$ vs. $70.66 \pm 16.57 \mathrm{ng} / \mathrm{ml}, p<0.001$ ) (Table I, Figure 1).

Men with CP compared to women with CP had the IGF-1 levels such as $85.03 \pm 62.16 \mathrm{ng} / \mathrm{ml}$ vs. 69.54 $\pm 37.87 \mathrm{ng} / \mathrm{ml}, p=0.489$. In the group with CP without DM the IGF-1 level was $91.13 \pm 65.48 \mathrm{ng} / \mathrm{ml}$ vs. 62.20 $\pm 32.38 \mathrm{ng} / \mathrm{ml}$ in the group with CP and DM, $p=0.077$. The duration of CP did not influence the IGF-1 level $(71.41 \pm 36.84 \mathrm{ng} / \mathrm{ml}$ in short-lasting CP up to 8 years of the disease vs. $81.45 \pm 48.85 \mathrm{ng} / \mathrm{ml}$ in long-lasting $\mathrm{CP}$ over 8 years, $p=0.462$ ). The presence of calcification did not affect the IGF-1 concentration (84.08 $\pm 73.22 \mathrm{ng} / \mathrm{ml}$ without calcification vs. $76.15 \pm 50.71$ 
Table II. IGF-1 level in CP patients depending on occurrence of cysts

\begin{tabular}{lccc} 
Parameter & Cysts $(-)$ & Cysts (+) & $P$-value \\
\hline IGF-1 $[\mathrm{ng} / \mathrm{ml}]$ & $60.35 \pm 34.68$ & $93.55 \pm 64.78$ & $<0.05$
\end{tabular}

CP-chronic pancreatitis, IGF-1 - insulin-like growth factor 1.

$\mathrm{ng} / \mathrm{ml}$ with calcification, $p=0.867)$. In CP without distinction of pancreatic ducts, the IGF-1 compared to CP with distinction of pancreatic ducts was (95.30 \pm 78.59 $\mathrm{ng} / \mathrm{ml}$ vs. $75.60 \pm 45.75 \mathrm{ng} / \mathrm{ml}, p=0.660$ ). In the group with CP without narrow main pancreatic duct, the IGF1 was $91.82 \pm 71.07 \mathrm{ng} / \mathrm{ml}$ vs. $72.09 \pm 54.29 \mathrm{ng} / \mathrm{ml}$ in the group with CP and narrow main pancreatic duct, $p=0.475$. Patients who had CP without cysts were noted to have a significantly lower level of IGF-1 compared to those with both CP and cysts $(60.35 \pm 34.68 \mathrm{ng} / \mathrm{ml}$ vs. $93.55 \pm 64.78 \mathrm{ng} / \mathrm{ml}, p<0.05$ ) (Table II, Figure 2).

In CP without DM, IGF-1 was higher compared to those with PDAC without DM $(91.13 \pm 65.48 \mathrm{ng} / \mathrm{ml}$ vs. $54.75 \pm 40.41 \mathrm{ng} / \mathrm{ml}, p<0.001)$. In patients with CP and DM the IGF-1 was also higher in comparison to patients with PDAC and DM $(62.20 \pm 32.38 \mathrm{ng} / \mathrm{ml}$ vs. $48.45 \pm 24.88 \mathrm{ng} / \mathrm{ml}, p<0.05$ ) (Table III).

The IGF-1 serum level in men with PDAC was similar to that in women with PDAC $(52.93 \pm 33.72 \mathrm{ng} / \mathrm{ml}$ vs. $53.47 \pm 38.94 \mathrm{ng} / \mathrm{ml}, p=0.882)$. In the group with PDAC without DM the IGF-1 as compared with those with PDAC and DM was $(54.75 \pm 40.41 \mathrm{ng} / \mathrm{ml}$ vs. 48.45 $\pm 24.88 \mathrm{ng} / \mathrm{ml}, p=0.514)$. In the group with PDAC and new-onset diabetes the IGF-1 level was $47.10 \pm 19.53$ $\mathrm{ng} / \mathrm{ml}$ compared to $57.43 \pm 36.28 \mathrm{ng} / \mathrm{ml}$ in patients with PDAC and longstanding DM, $p=0.35$. There was also no statistically significant difference in the PDAC group without and with DM in the subgroup: new-onset DM and longstanding DM, respectively $(54.75 \pm 40.41 \mathrm{ng} / \mathrm{ml}$ in DM vs. $47.10 \pm 19.53 \mathrm{ng} / \mathrm{ml}$ in new-onset $\mathrm{DM}, p=$ 0.919 and $54.75 \pm 40.41 \mathrm{ng} / \mathrm{ml}$ in DM vs. $57.43 \pm 36.28$ $\mathrm{ng} / \mathrm{ml}$ in longstanding DM, $p=0.954)$.

The serum IGFBP-2 level was significantly higher in CP patients compared to PDAC patients (512.42 \pm 299.77 $\mathrm{ng} / \mathrm{ml}$ vs. $301.59 \pm 190.36 \mathrm{ng} / \mathrm{ml}, p<0.001)$. In the CP and PDAC group the IGFBP-2 serum level was significantly elevated compared to the control group (512.42 $\pm 299.77 \mathrm{ng} / \mathrm{ml}$ vs. $51.92 \pm 29.40 \mathrm{ng} / \mathrm{ml}, p<0.001$ and $301.59 \pm 190.36 \mathrm{ng} / \mathrm{ml}$ vs. $51.92 \pm 29.40 \mathrm{ng} / \mathrm{ml}$,

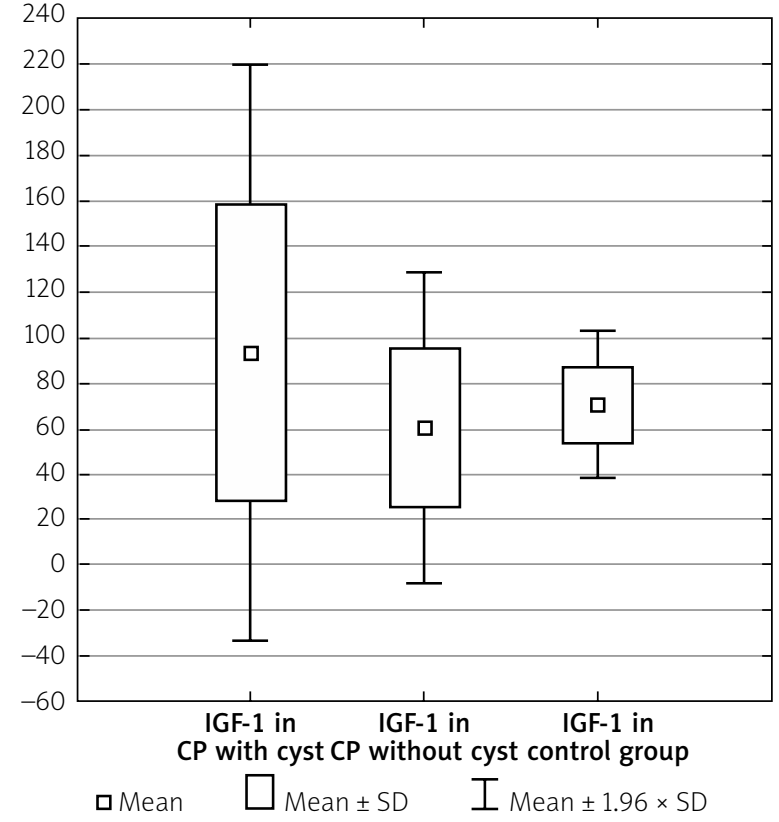

Figure 2. IGF-1 level in CP depending on occurrence of cysts

CP-chronic pancreatitis, IGF-1 - insulin-like growth factor 1 .

$p<0.001$ ) (Table I, Figure 3). IGFBP-2 in CP without DM was also higher compared to those with PDAC and without DM (559.39 \pm 281.43 vs. $296.53 \pm 196.93, p<$ 0.001) (Table IV).

IGFBP-2 in men with CP was $534.54 \pm 288.76 \mathrm{ng} /$ $\mathrm{ml}$ vs. women with $\mathrm{CP} 442.18 \pm 331.74 \mathrm{ng} / \mathrm{ml}, p=$ 0.329. In CP without DM, the IGBP-2 level was 559.39 $\pm 281.43 \mathrm{ng} / \mathrm{ml}$ vs. $504.90 \pm 330.90 \mathrm{ng} / \mathrm{ml}$, in those with $\mathrm{CP}$ and $\mathrm{DM}, p=0.776$. In patients with short time of CP duration, the IGFBP-2 was $447.28 \pm 308.13 \mathrm{ng} / \mathrm{ml}$ vs. $299.70 \pm 225.69 \mathrm{ng} / \mathrm{ml}$, in the group with long duration of $C P, p=0.235$. In CP without calcification the IGFBP-2 was $615.59 \pm 226.24 \mathrm{ng} / \mathrm{ml}$ vs. patients with $\mathrm{CP}$ and calcifications $551.55 \pm 303.08 \mathrm{ng} / \mathrm{ml}, p=0.433$. In the group with $\mathrm{CP}$ and normal pancreatic ducts the

Table III. IGF-1 (ng/ml) level in CP and PDAC patients depending on diabetes

\begin{tabular}{lccc} 
Diabetes mellitus & 83 CP & 92 PDAC & P-value \\
\hline$(-)$ & $91.13 \pm 65.48$ & $54.75 \pm 40.41$ & $<0.001$ \\
\hline$(+)$ & $62.20 \pm 32.38$ & $48.45 \pm 24.88$ & $<0.05$
\end{tabular}

CP - chronic pancreatitis, PDAC - pancreatic adenocarcinoma, IGF-1 - insulin-like growth factor 1. 


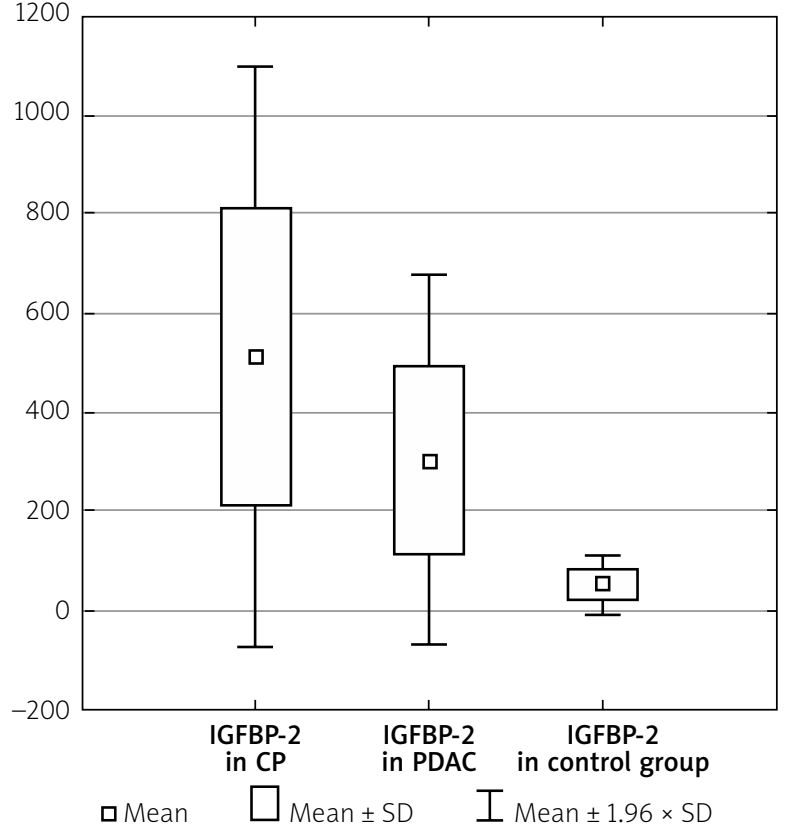

Figure 3. IGFBP-2 level in the CP, PDAC, and control groups

$C P$ - chronic pancreatitis, PDAC - pancreatic adenocarcinoma, IGFBP-2 - insulin-like growth factor binding protein 2

IGFBP-2 was $588.25 \pm 274.05 \mathrm{ng} / \mathrm{ml}$ vs. $531.61 \pm 309.02$ $\mathrm{ng} / \mathrm{ml}$ among those with extended pancreatic ducts, $p=0.508$. In CP without narrow main pancreatic ducts, IGFBP-2 was $637.35 \pm 259.05 \mathrm{ng} / \mathrm{ml}$ vs. $712.00 \pm 197.70$ $\mathrm{ng} / \mathrm{ml}$ in CP with constricted main pancreatic duct, $p=$ 0.371. Patients with CP without cysts did not differ from those with both CP and cysts $(563.52 \pm 276.24 \mathrm{ng} / \mathrm{ml}$ vs. $540.94 \pm 298.94 \mathrm{ng} / \mathrm{ml}, p=0.767)$.

IGFBP-2 in men with PDAC was $284.44 \pm 167.44 \mathrm{ng} /$ $\mathrm{ml}$, and in women with PDAC the IGFBP-2 was 320.79 $\pm 213.56 \mathrm{ng} / \mathrm{ml}, p=0.767$. In the PDAC group without DM, the IGFBP-2 was $296.53 \pm 196.93 \mathrm{ng} / \mathrm{ml}$ in comparison to PDAC and DM $312.57 \pm 183.70, p=0.327$. Between new-onset DM vs. longstanding DM in the course of PDAC, the IGFBP-2 level was $283.89 \pm 190.97$ $\mathrm{ng} / \mathrm{ml}$ vs. $375.98 \pm 187.78, p=0.173$. The IGFBP-2 level did not depend on whether there was no DM or DM was new-onset during PDAC (296.53 $\pm 196.93 \mathrm{ng} / \mathrm{ml}$ vs. $283.89 \pm 190.97 \mathrm{ng} / \mathrm{ml}, p=0.940)$. IGFBP-2 in PDAC without DM did not differ from IGBP-2 in PDAC with longstanding DM $(296.53 \pm 196.93 \mathrm{ng} / \mathrm{ml}$ vs. 375.98 $\pm 187.78, p=0.071)$.

\section{Discussion}

There are a relatively small number of publications assessing both IGF-1 and IGFBP-2 levels among patients with CP and PDAC. It is extremely important to look for new biomarkers that enable the differentiation of PDAC and endocrine disorders which might be distinguished as one of as the first symptom of PDAC.

Pancreatic diabetes accounts for only $5-10 \%$ of all cases of DM [24]. However, new-onset diabetes caused by the cancer appears to be a clinically useful marker of asymptomatic PDAC [25]. In many PDAC patients, onset of DM occurs when they would have no cancer-related symptoms. Thus, new-onset DM is the only clue to the presence of asymptomatic PADC. The high prevalence of diabetes in small tumours $<2 \mathrm{~cm}$, early stage tumours, and the onset of diabetes nearly 2 years before diagnosis and prior to radiologically detectable tumour tends to favour a humoral process rather than a tumour local effect [26]. These data suggest that new-onset DM in pancreatic cancer is probably induced by the tumour, which is not likely to be explained simply by tumour-induced gland destruction. In our opinion, IGF-1 may be an indicator that signals whether pancreatic diabetes is from CP or PDAC. Our results show that diabetes does not have an influence on IGF-1 levels in PDAC patients. The IGF axis, especially IGF-1, may be a factor closely related to the onset of PDAC due to its impact on glucose metabolism. Our outcome can be explained by the ability of insulin to activate IGF-1 receptors through hyperinsulinaemia and insulin resistance [27]. According to the study by Basso et al., IGF-1 could be involved in influencing glucose homeostasis [28]. In another study, no correlation was found between IGF-1 and tumour size or stage, but its level was inversely correlated with fasting serum glucose levels $(p<0.05)$ [29].

Elevated levels of IGF-1 are observed in colorectal, prostate, lung, and breast cancer [26, 30]. In our study the PDAC patients were characterised by a lower IGF-1 serum level. Some epidemiological studies have shown that a high concentration of IGF-1 is observed in CP and PDAC, more so than in the controls, but others did not confirm that finding $[28,29]$. States in which insulin is markedly elevated are associated with lower serum IGF-1 concentrations [29]. As PDAC is characterised by insulin resistance and increased insulin levels, this could explain the reduced level of IGF-1 among our patients.

Table IV. IGFBP-2 (ng/ml) level in CP and PDAC patients without diabetes

\begin{tabular}{lccc} 
Diabetes mellitus & $\mathbf{8 3 ~ C P}$ & 92 PDAC & $P$-value \\
\hline$(-)$ & $559.39 \pm 281.43$ & $296.53 \pm 196.93$ & $<0.001$
\end{tabular}

CP - chronic pancreatitis, PDAC - pancreatic adenocarcinoma, IGFBP-2 - insulin-like growth factor binding protein 2). 
We indicate that IGF-1 and IGFBP-2 are good biomarkers in recognising pancreatic diseases. Moreover IGF-1 may be an indicator that signals whether pancreatic diabetes comes from CP or PDAC, and it may indicate the presence of a pancreatic cyst in CP patients. Karna et al. suggested that disturbances in tissue collagen metabolism during pancreatic diseases may result from deregulation of IGF-1 homeostasis. This could be an explanation for our differing results, because we know that IGF-1 stimulates collagen biosynthesis through interaction with IGF-1 receptor. Moreover, IGFBPs regulate the activity of IGF-1 [30, 31].

The level of IGFBP-2 is reported to be increased in PDAC patients' serum, in accordance with our results $[29,32]$. According to other authors, the study shows a 2.5-fold increase in serum levels of IGFBP-1 in patients with CP and about a six-fold increase in serum of patients with PDAC [31]. In our results, IGFBP-2 levels were 9.9-fold increased in the CP group compared to controls, and 5.8-fold in PDAC patients. In the study by Yoneyama et al., the results revealed that IGFBP-2 and IGFBP-3 have the ability to discriminate PDAC patients at an early stage from healthy controls, and IGFBP-2 appeared to show an increased risk in diseases of pancreatic malignancy. Furthermore, diagnosis of PDAC using the combination of carbohydrate antigen 19-9 (CA19-9), IGFBP-2, and IGFBP-3 is significantly more effective than CA19-9 alone. Early diagnosis with this marker combination may improve the prognosis of PDAC patients [20].

We show that the IGFBP-2 level is lower when compared to patients with CP. Diabetes co-occurrence did not influence IGFBP-2 levels in our PDAC group. Some research reports that the level of IGFBP-2 increased slightly as the clinical stage became more advanced. IGFBP-2 should preferably be released/induced/produced by the cancer and should correlate with tumour burden, increasing with tumour growth [20, 32]. In the collaborative meta-analysis by Gong et al. the results showed for the first time that serum IGF-1, IGF-2, IGFBP-1, and IGFBP-3 concentrations as well as the IGF-1/IGFBP-3 ratio were not associated with risk of PDAC. Sub-group analysis also did not show any significant associations [15].

In our study, the mean age of patients diagnosed with PDAC was higher compared to the CP group and was about 66 years, which could have an effect on lowering the level of IGF-1 level. Numerous studies observed that as the body ages, the levels of IGF-1 and IGFBP-3 decrease [33]. Among patients over 65 years of age, low IGFBP-1 levels are associated with an increased incidence of glucose tolerance disorders [34]. In the presence of carbohydrate disorders, IGF-1 and IGFBP-1 levels are lower among middle-aged patients. There are no statistically significant differences in IGF-1 among older patients, which may be due to progressive metabolism disorders [33]. Lowering the previously increased result in CP could be an indicator of the development of PDAC against the background of CP.

\section{Conclusions}

It is extremely important to search for PDAC biomarkers that enable detection of cancer at an early stage of its development. However, it should be taken into account that biochemical tests can only have a complementary and auxiliary meaning compared to imaging tests. Due to the frequent occurrence of diabetes in the course of PDAC, the detection of a protein that differentiates pancreatic diabetes from other endocrine disorders may be crucial. In our study IGF-1 and IGFBP-2 are good biomarkers of pancreatic diseases, especially CP and PDAC. IGF-1 may be an indicator that signals whether pancreatic diabetes is from CP or PDAC. Non-specific biomarkers, regardless of their value, even more than specific biomarkers, can only have complementary significance in the context of other results, especially visualising ones, and they cannot replace full diagnostics in accordance with current recommendations.

\section{Acknowledgments}

The research was financed by the Medical University of Lodz from the research task number 502-03/1-00201/502-14-245.

\section{Conflict of interest}

The authors declare no conflict of interest.

\section{References}

1. Hardt PD, Brendel MD, Kloer HU, Bretzel RG. Is pancreatic diabetes (type $3 c$ diabetes) underdiagnosed and misdiagnosed? Diabetes Care 2008; 31: 165-9.

2. Rickels MR, Bellin M, Toledo FG, et al. PancreasFest Recommendation Conference Participants. Detection, evaluation and treatment of diabetes mellitus in chronic pancreatitis: recommendations from PancreasFest 2012. Pancreatology 2013; 13: 336-42.

3. Malka D, Hammel P, Sauvanet A, et al. Risk factors for diabetes mellitus in chronic pancreatitis. Gastroenterology 2000; 119 : 1324-32.

4. Miyahara T, Kawabuchi M, Goto M, et al. Morphological study of.pancreatic endocrine in an experimental chronic pancreatitis with diabetes induced by stress and cerulein. Ultrastruct Pathol 1999; 23: 171-80.

5. Niebisz-Cieślak A, Karnafel W. Insulin sensitivity in chronic pancreatitis and features of insulin resistance syndrome. Pol Arch Med Wewn 2010; 120: 255-63. 
6. Angelopoulos N, Dervenis C, Goula A, et al. Endocrine pancreatic insufficiency in chronic pancreatitis. Pancreatology 2005 5: $122-31$.

7. Chari ST, Klee GG, Miller LJ, et al. Islet amyloid polypeptide is not a satisfactory marker for detecting pancreatic cancer Gastroenterology 2001; 121: 640-5.

8. Skoudy A. Embryonic pancreas development links with pancreatic diseases. In: Exocrine pancreas cancer. The European Pancreatic Cancer-Research Cooperative (EPC-RC). Gress TM, Neoptolemos JP, Lemoine NR, Real FX (eds). Felsenstein CCCP, Hanover 2004; 97.

9. Pour PM. Clinical assessment of pancreatic cancer: is there a chance for early diagnosis? In: Clinical Pancreatology for Practicing Gastroenterologists and Surgeons. DominquezMunoz JE (ed.). Blackwell Publishing, Oxford UK 2007; 366, 369, 370, 372, 373, 374

10. Livingstone C. Insulin-like growth factor-I (IGF-I) and clinical nutrition. Clin Sci 2013; 125: 265-80.

11. Juul A. Serum levels of insulin-like growth factor-I and its binding proteins in health and disease. Growth Horm IGF Res 2003, 13: 113-70.

12. Pavelic J, Matijevic T, Knezevic J. Biological and physiological aspects of action of insulin-like growth factor peptide family. Indian J Med Res 2007; 125: 511-22.

13. $\mathrm{Yu} \mathrm{H}$, Rohan T. Role of the insulin-like growth factor family in cancer development and progression. J Natl Cancer Inst 2000, 92: 1472-89.

14. Saukkonen T, Amin R, Williams RM, et al. Dose-dependent effects of recombinant human insulin-like growth factor (IGF)-I/ IGF binding protein-3 complex on overnight growth hormone secretion and insulin sensitivity in type 1 diabetes. J Clin Endocrinol Metab 2004; 89: 4634-41.

15. Gong Y, Zhang B, Liao Y, et al. Serum insulin-like growth factor axis and the risk of pancreatic cancer: systematic review and meta-analysis. Nutrients 2017; 18: 9.

16. Chi F, Wu R, Zeng YC, et al. Circulation insulin-like growth factor peptides and colorectal cancer risk: an updated systematic review and meta-analysis. Mol Biol Rep 2013; 40: 3583-90.

17. Cousin SP, Hugl SR, Wrede CE, et al. Free fatty acid-induced inhibition of glucose and insulin-like growth factor I-induced deoxyribonucleic acid synthesis in the pancreatic beta-cell line INS-1. Endocrinology 2001; 142: 229-40.

18. Williams T, Berelowitz M, Joffe SN, et al. Impaired growth hormone responses to growth hormone-releasing factor in obesity. A pituitary defect reversed with weight reduction. N Eng J Med 1984; 311: 1403-7.

19. Wheatcroft SB, Kearney MT, Shah AM, et al. IGF-binding protein-2 protects against the development of obesity and insulin resistance. Diabetes 2007; 56: 285-94.

20. Yoneyama T, Ohtsuki S, Honda K, et al. Identification of IGFBP2 and IGFBP3 as compensatory biomarkers for CA19-9 in early-stage pancreatic cancer using a combination of antibody-based and LC-MS/MS-based proteomics. PLoS One 2016 1: e0161009.

21. Hoeflich A, Reisinger R, Lahm H, et al. Insulin-like growth factor-binding protein 2 in tumorigenesis: protector or promoter? Cancer Res 2001; 61: 8601-10.
22. Baxter RC. IGF binding proteins in cancer: mechanistic and clinical insights. Nat Rev Cancer 2014; 14: 329-41.

23. Azar WJ, Zivkovic S, Werther GA, Russo VC. IGFBP-2 nuclear translocation is mediated by a functional NLS sequence and is essential for its pro-tumorigenic actions in cancer cells. Oncogene 2014; 33: 578-88.

24. Cui Y, Andersen DK. Pancreatogenic diabetes: special considerations for management. Pancreatology 2011; 11: 279-94.

25. Pannala R, Basu A, Petersen GM, Chari ST. New-onset diabetes: a potential clue to the early diagnosis of pancreatic cancer. Lancet Oncol 2009; 10: 88-95.

26. Chari ST, Leibson CL, Rabe KG, et al. Pancreatic cancer associated diabetes mellitus: prevalence and temporal association with diagnosis of cancer. Gastroenterology 2008; 134: 95-101.

27. Kwon J, Stephan S, Mukhopadhyay A, et al. Insulin receptor substrate-2 mediated insulin-like growth factor-I receptor overexpression in pancreatic adenocarcinoma through protein kinase Cdelta. Cancer Res 2009; 69: 1350-7.

28. Basso D, Plebani M, Fogar P, et al. Insulin-like growth factor-I, interleukin-1 alpha and beta in pancreatic cancer: role in tumor invasiveness and associated diabetes. Int J Clin Lab Res 1995; 25: 40-3.

29. Meggiato T, Plebani M, Basso D, et al. Serum growth factors in patients with pancreatic cancer. Tumour Biol 1999; 20: 65-71.

30. Heidegger I, Massoner P, Sampson N, Klocker H. The insulin-like growth factor (IGF) axis as an anticancer target in prostate cancer. Cancer Lett 2015; 367: 113-21.

31. Karna E, Surazynski A, Orłowski K, et al. Serum and tissue level of insulin-like growth factor-I (IGF-I) and IGF-I binding proteins as an index of pancreatitis and pancreatic cancer. Int J Exp Pathol 2002; 83: 239-45.

32. Kendrick ZW, Firpo MA, Repko RC, et al. Serum IGFBP2 and MSLN as diagnostic and prognostic biomarkers for pancreatic cancer. HPB 2014; 16: 670-6.

33. Johnson SC. Nutrient sensing, signaling and ageing: the role of IGF-1 and mTOR in ageing and age-related disease. Subcell Biochem 2018; 90: 49-97.

34. Kendrick ZW, Firpo MA, Repko RC, et al. Serum IGFBP2 and MSLN as diagnostic and prognostic biomarkers for pancreatic cancer. HPB 2014; 16: 670-6.

Received: 17.04 .2020

Accepted: 24.04 .2020 